\title{
NOTA SOBRE A CENOGRAFIA E O VESTUÁRIO NO TARTUFO DE PLANCHON
}

Há um aspecto do "Tartufo" de Planchon que me parece ter sido pouco valorizado pela crítica teatral e é provavelmente fundamental: é a significação que se desvenda no ú'timo ato do espetáculo.

Os desenlaces de Molière são frequentemente tidos como expedientes teatrais que tornam possibel encerrar rapidamente o enredo, após que o esséncial (desluvalvimento dos personagens e suas relações) tenha sldo dito. São "coups de théâ tre" que permitem concluir a comédia de modo brilhante (muita ação, personagens novos) e num tom alegre, nem sempre lógico com o drama que precede. São desenlaces "artificiais", que às vezes apelam até para o sobrenatural: neste último caso chegaria a estar incluído o "Tartufo" (intervenção do rei como deus ex-machina), conforme os críticos Lagarde e Michard, oráculos literários nos ginásios e colégios franceses.

Planchon optou por uma posição oposta: o desenlace não é um expediente, ele tem uma singificação precisa em si e esta significação esclarece tudo o que precede. Por isto, o espetáculo de Planchon só se revela no final, exigindo do espectador uma reflexão retrospectiva sobre o espetáculo.

Com Planchon, o cofre de Orgon não é um artifício teatral, mas o próprio segredo que explica a ação: o cofre contém documentos que provocam que Orgon, fiel ao rei na sua juventude, envolveu-se posteriormente numa conspiração contra - rei. Tartufo passa a ser então um agente do rei que age contra os burgueses que se colocam contra o rei. $E$ é por isto também que Tartufo quer obter a casa de Orgon: trata-se de reaver uma casa aristocrática que foi tomada pelo burguês. Nesta concepção, "Tartufo" é um episódio da luta entre a nobreza e a burguesia, e essa luta é violenta: o rei empresta seus soldados a Tartufo e Orgon é vítima de uma verdadeira repressão policial. A descida dos burgueses no fosso é uma espécie de revolução Francesa: às avessas a nobresa extermina a burguesia.

Naturalmente, a ação não pode parar aí: ela seria historicamente falsa e teria sido interditada; além do que Molière não é um autor do século XVIII. A ação se encerra com um expediente, mas que é, no espetáculo de Planchon, antes um expediente ideológico que teatral. O expediente consiste em transformar o debate político em questão ética: a generosidade do monarca perdoa Orgon, porque este, na juventude, foi leal, e a lealdade o rei nunca esquece, etc. A marcação salienta o caráter artificial e provisório deste desenlace: o tom mun- 
dano e superficial com que se comporta o ator que interpreta o emissário do rei contrasta com a interpretação de todos os outros atores e marca a fragilidade desta resolução. Por outro lado, este compromisso é historicamente viável: a nobreza está mais preocupada em domesticar a burguesia do que em acabar com ela, e a burguesia não exclui possibilidade de entendimento com o nobreza (a própria fascinação de Orgon por Tartufo mostra que as posiçōes do burguês, por mais conspirador que seja, não são radicais). Mas o compromisso não é uma verdadeira solução: após a saida do emissário do rei, Orgon está abatido e solitário, nem a generosidade do rei, nem o casamento tão almejado conseguem dar-lhe alegria. E um dia virá em que a nobreza será enforcada: o futuro ecoa, ainda incerto, no espetáculo de Planchon. Enquanto Tartufo é amordaçado no primeiro plano, no fundo seu criado é inesperadamente enforcado. A corda que cai do teto da casa do burguês para a simulação de enforcamento éo verdadeiro deus ex-machina do espetáculo de Planchon.

Esta interpretação do final do espetáculo esclarece outros elementos da montagem, particularmente a cenografia e o vestuário. A cenografia indica uma casa aristocrática em ruínas. Aos símbolos do fausto antigo, juntam-se símbolos do trabalho: são as máquinas que transformam a casa em obra; a casa está sendo ou vai ser reformada. Este momento da casa expressa a situação do burguês: ele tomou posse de um bem da nobreza, está portanto em oposição a ela, mas está também compromissado com ela, por estar numa casa que pertenceu à aristocracia; mas ele não está numa posição consolidada (a reforma da casa não foi feita). Não é um estado, é um processo. A dinâmica da cenografia vai no mesmo sentido: o levantar progressivo dos telóes não representa tanto uma ampliação do espaço que acompanha o desenvolvimento psicológico dos personagens (conforme interpretação de alguns críticos), como, basicamente, o desvendamento paulatino da coisa que será objeto do último embate da peça: a casa, a posse da casa (talvez o poder). O levantar dos telōes (que corresponde à divisão em atos) acompanha a progressão do espetáculo. Assim como só no último ato o espetáculo revelará sua significação, só com o levantar do último telão aparecerá a porta pela qual entrarão Tartufo e os soldados do rei para tomar posse da casa. As entradas e saídas podem ser parcialmente elucidadas por esse processo: as duas portas laterais são as portas da burguesia; as do fundo são as portas da nobreza: primeiro o buraco de rato de Tartufo (a nobreza mina a burguesia para reaver a casa), e finalmente a porta mais de castelo que de casa para a entrada militar da nobreza.

O vestuário também situa a posição do burguês no jogo oposição-compromisso com a nobreza. Duas cores dominam as roupas: o preto e o branco-bege. O branco é a cor dos burgueses, o preto não é apenas a cor da devoção, é a cor do rei: cor de Tartufo, dos soldados e do emissário do rei. Uma exceção para o emissário: seu casaco e chapeu pretos são ornamentados de plumas brancas: ele é o personagem do compromisso. A inversão (e a oposição-compromisso) é clara: o branco é que é a cor da realeza (e o preto 
é também a cor dos CRS, os soldados da repressão dos governos. De Gaulle-Pompidou.

Os burgueses vestem-se de cor clara, com exceção da mãe no primeiro ato, que tem a cor de Tartufo (compromisso). Mas essa cor clara é o branco fôsco de roupas intimas. Por mais inesperado que seja representar "Tartufo" de roupas de baixo, é perfeitamente funcional: o espetáculo burguês não está pronto, as roupas de aparato da burguesia não estão prontas. As roupas de baixo salientam, como a cenografia, que o espetáculo representa um processo, o que é acentuado pelas inúmeras vezes em que os atores se vestem e desvestem (Orgon se desveste na sua primeira cena, sua filha se veste antes do encontro com o namorado, Tartufo acaba de se vestir na sua primeira aparição, etc.). O desvestir do burgues talvez possa ser associado à incerteza de sua posição: Orgon se desveste lenta e metodicamente na sua primeira aparição no palco, o que é acompanhado pela revelação progressiva da sua alienação em relação a Tartufo, e simultânamente seu cunhado se veste, não menos lenta e metodicamente, o que é acompanhado pela revelação das suas seguras posições católicas.

Outro aspecto do vestuário é que as roupas de baixo são quase as mesmas para os burgueses como para seus criados: ambos se misturam. Há de fato alguma aliança momentânea possível, como fase do processo, entre os burgueses e o povo, num momento em que a burguesia não está consolidada e sua luta contra a nobreza ainda é incerta. Não é por acaso que se fez da criada, não só uma governanta, mas uma roupeira, que fica manipulando roupa de modo acintosamente gratuito.

Estas notas não elucidam todos os aspectos do espetáculo de Planchon (em particular não elucidam a linra da interpetração dada à personagem de Tartufo) mas certamente contribuem para compreender a linha mestra do espetáculo.

Resta a dizer que, no contexto brasileiro, este espetáculo é pouco importante: tudo isto e muito mais poderia se dizer, e mais claramente, com outro texto. Sobre muitos dos problemas ventilados por Planchon, o espetáculo do Teatro São Pedro “A queda da Bastilha???" diz, em termos brasileiros, muito mais. Mas é certamente um espetáculo importante em termos franceses: como não se coloca em dúvida a grandeza do Grande Século, a historização (em termos dos conflitos sociais da época - e não superficial transposição para conflitos atuais) proporciona um material válido para a reflexão: os classicos podem ser reinterpretados, e não apenas cultuados. Mas, o espetáculo de Planchon tem sentido só porque e onde os clássicos são cultuados. 